\title{
Perceived Service Quality (SQ) and Customer Satisfaction (CS): Students' Perceptions of Kenyan Private Universities
}

\author{
Eric E. Mang'unyi \\ University of KwaZulu-Natal \\ Email: mangunyie@gmail.com \\ Prof. Krishna K. Govender \\ University of KwaZulu-Natal, and \\ Regenesys Business School \\ Email: krishnag@regenesys.co.za
}

\section{Doi:10.5901/mjss.2014.v5n23p2739}

\section{Abstract}

This paper illustrates the relationship between service quality (SQ) and customer satisfaction (CS)through empirical evidence using structural equation modeling of data collected through a survey conducted among a sample of 522 students at private universities in Kenya, aself-administered questionnaire was used to collect data classified on Higher Education Performance Model (HEdPERF) framework, comprising non-academic, academic, reputation, access, programme issues and understanding aspects of SQ. The results revealed that the six SQ dimensions of HEdPERF needed to be collapsed into four variables of SQ that were significant to students of private universities. Furthermore, the dimensions had a positive and significant relationship with $S Q$, and in turn influenced CS. Recommendations are made to the university managers and higher education policy makers to improve $S Q$ by taking note of the importance of the variables identified as being of benefit to customers, as quality services improve satisfaction, university's competitiveness and excellence.

Keywords: Service Quality; Customer Satisfaction; Private Higher Education.

\section{Introduction}

In recent times, service quality measurement has raised lots of interest not only in scholarship (De Jager \& Gbadamosi, 2010; DeShields Jr, Kara \& Kaynak, 2005; Firdaus, 2006, Ong \& Nankervis, 2012), but also among education providers, including universities. Quality of service and customer satisfaction by private universities is a subject that cannot be undervalued in management studies and the strategic planning processes. They are inherent attributes that if rightly implemented will create positive customer experiences which would translate to good organizational performance, cost reduction, increased market shares and surpluses (Zeithaml, Bitner \& Gremler, 2009).

Whereas certain private universities have been acknowledged to attract customers particularly students due to factors such as religious faith (Nguru, 1990; Onsongo, 2011), programmes offered (Murphy, 2009), unique student experience and also retention of skilled human capital (Materu, 2007) among other factors, with increased competition other aspects such as the quality of service may play a bigger role in dictating allegiance and satisfaction. Additionally, the extant literature on the aforementioned subject in the context of higher education sector is ever-increasing (Alaba \& Olanrewaju, 2012; Calvo-Porall, Levy-Mangin \& Novo-Corti, 2013; DeJager \& Gbadamosi, 2010; Govender \& Ramroop, 2012; Hasan \& Ilias, 2008; Hishamuddin \& Azleen, 2008; Khodayari \& Khodayari, 2011; Trivellas \& Dargenidou, 2009; Yunus, Ismail, Ishak \& Juga, 2009).

While it is factual that Kenya has experienced high demand for higher education services, and despite the unprecedented expansion and growth in higher education provision, there is still a gap in research on service quality and customer satisfaction. In an attempt to address the aforementioned, this study empirically evaluated the relationship between SQ and satisfaction (CS) among students (undergraduates and postgraduates) in Kenyan Private Universities. Broadly, the study attempted to identify critical dimensions of university service quality, assess the dimensions of quality that contribute to customer satisfaction, and determine the association between SQ and CS. 


\section{Literature Review}

\subsection{Service Quality in the Higher Education Context}

Despite on-going and growing debate and the extant literature on service quality and more especially how it is perceived, researchers (Bendapudi \& Leone, 2003; Yoon, Seo \& Yoon, 2004) seem to agree that since services are concurrently created and consumed, then quality has to be determined by the stakeholders. Gronroos (2000) asserts that customers become partners through participation, and for this to succeed, organizations need to design and put in place systems that encourage service providers to put into practice and foster participation of customers into the process (Yoon, Seo \& Yoon 2004). Meaningful participation of customers in the service process ensures quality input and subsequently quality outcomes (Zeithaml, Bitner \& Gremler, 2006), and organisations that accommodate customers' suggestions will strive to offer quality services and more appealing (Ojo, 2010).

Higher education institutions (HEls) experience great challenges in the implementation of quality-based practices, because defining service quality in higher education institutions has proved to be a major challenge (Quinn, Lemay, Larson \& Johnson, 2009). The aforementioned researchers have defined service quality in higher education in terms of educational, administration and supporting services.

Trivellas and Dargenidou (2009) assert that service quality can be enhanced if there is sustainability in clarity, accuracy and reliability of the services provided with no particular aspect standing out to both internal and external customers of the institution. Furthermore, Govender and Ramroop (2012) argue that in higher education a supporting environment for internal customers to understand their roles in creating a service, will impact the perceptions of service, an implication for universities to promote a positive environment that will improve perceptions of the service provider. DeShields Jr, Kara and Kaynak (2005) have shown that a positive service experience will engender satisfaction among students with a university. Furthermore, high value and a focus on individual needs will raise the positive climate created by the institution (Adela, 2008). Thus, universities need to offer high quality services for differentiation and effective competition in the sector. A focus on core university functions will serve as distinct differentiators leading to quality services (Ong \& Nankervis, 2012).

\subsection{The Higher Education Student - A Customer}

The debate on whether a student is a customer or not has been raging for many years and two different approaches have been adopted in the way Higher Education Institutions (HEIs) treat the students, namely the customer-oriented (studentcustomer) approach, and the student-product approach. Many researchers (Lovelock \& Young, 1979; Zeithaml \& Bitner, 1996; Bateson, 2002) especially those in the service marketing disciplines proceed from a premise that the student is a consumer and/or co-producer of the education service. However, some (Franz, 1998; Albanese, 1990; Emery, Kramer \& Tian, 2001) contend that students should not be viewed as customers. ${ }^{1}$ Carrol (2007) argues that Lisa Bevill, the Associate Director of Admissions at a business school in Madrid believes that the 'student as customer' debate treads a fine line and is, perhaps, too simplistic a definition for what becomes a life-long relationship. "It implies the concept that the customer is always right and should be treated as such. However, this is hardly the case with MBA students and we should not lose sight of this because the relationship between MBA student and school is more profound."

Despite the differing views, there is overwhelming support for viewing students as customers and adopting the principles of customer service and Total Quality Management to the education environment (Conway, Mackay \& Yorke, 1994; John, 1998; Bejou, 2005; Obermiller, Fleenor \& Raven, 2005). Moreover, some researchers, inter-alia, Marcel and Harris (2000) argue that whether we view the student as a customer or not, depends on how we define a customer. If we think customers need specialized services and our assistance to accomplish a task and, if we believe students are full partners in their education and can help us improve our teaching through their thoughtful comments, then they should be considered as our primary customers. ${ }^{2}$

\subsection{Service Quality and Customer Satisfaction}

Many research studies aimed at determining university customers' perceptions of service quality and satisfaction have shown that a correlation exists between the two constructs. For example, Ham and Hayduk (2003) who explored the

${ }^{1}$ The debate continues and further discussion is not necessary since this is not the purpose of this paper.

${ }^{2}$ This view is adopted in this paper; thus all reference to the customer should be regarded as the university student. 
relationship between the five dimensions of SERVQUAL (Parasuraman, Zeithaml \& Berry, 1988), found that every dimension of service quality had a positive relationship with satisfaction, with Reliability having the strongest relationship, followed by Responsiveness, Empathy, Assurance and Tangibility. Combrinck's (2006) study on students' perceptions of service quality at the Management Department of a university in South Africa revealed that there was uncertainty among undergraduates in their attitude to service quality in the department, while postgraduate students' ratings of service quality were more negative. Wang and Shieh (2006) who looked at the importance of CS and SQ and service performance of a library in Taiwan found that overall, service quality has a significantly positive effect on the overall satisfaction, with Tangibles, Reliability, Assurance and Empathy, and a statistically significant effect on overall satisfaction.

Hasan and llias (2008) argued that Empathy and Assurance were critical factors that contribute most to students' satisfaction. In the aforementioned study on perceived service quality among 200 undergraduate students at two private higher education institutions, age, tangibility, responsiveness and reliability were less significant, compared to empathy and assurance which had a greater influence on the rest. In a study in Malaysian higher education institutions, it was determined that all the quality attributes had a significant relationship with students' satisfaction, and highly correlated with one another (Hishamuddin \& Azleen, 2008). Prugsamatz, Pentecost and Ofstad (2006) conducted a study among Chinese students in Australia' to determine their expectations of overseas universities in terms of explicit and implicit service promises. The findings revealed that influential sources of information on students' expectations of universities were inter alia, past experiences, advertising, and word of mouth. It was therefore suggested that the more a consumer is exposed to explicit and implicit service promises, the higher the desired and predicted expectations of the university's service quality.

A survey among 150 Malaysian public university students using the SERVQUAL instrument through a hierarchical regression analysis demonstrated that reliability, responsiveness, assurance and empathy significantly correlated with customer satisfaction. Khodayari and Khodayari (2011) recognized that perceived service quality reflects the difference between consumer expectations and perceptions, which depends on the size and direction of the four gaps related to the delivery of service quality on the providers' side.

\subsection{Service Quality Measurement - The HEdPERF Instrument}

Since education is essentially a service industry, consequently its management practices are typically concerned with issues such as quality, which fall within the aegis of services marketing. Service delivery and customer satisfaction in an education environment are dependent on the personal interaction between students and staff, and this personal interaction, and the labour intensive nature of this service translates into a potentially highly heterogeneous quality service experience (Hill 1995, as cited by De Jager \& Gbadamosi, 2010: 253). The service-quality-service performance (Cronin and Taylor, 1994) debate has also been on-going for a while, with much of the discussion revolving around the use of the 'gap' measures and, there seems to be equally strong support for the use of performance-based measures (Babakus \& Mangold, 1992, as cited by Cronin \& Taylor, 1994: 126).

Despite its extensive and popular use in higher education (HE) quality measurement (Sunanto, Taufiquarrahman \& Pangemanan, 2007; Rajasekhar, Muninarayanappa \& Reddy, 2009; Shekarchizadeh, Rasli \& Hon-Tat, 2011) the SERVQUAL instrument was not used in this study, since Alridge and Rowley (1998) assert that its application in higher education has not been without criticism. Some of the criticisms include the need to ask the same questions twice, and the fact that the instrument captures a snapshot of perceptions at one point in time. However, Hair et al. (2006: 11), asserts that the work carried out so far using SERVQUAL in a higher education context would seem to suggest that the instrument can be used successfully, as long as the modifications are kept to a minimum.

In view the criticisms and or limitations of using the SERVQUAL instrument to measure service quality in the higher education environment, the HE performance-only model (HEdPERF) developed by Firdaus (2005) was adapted and customized in this study. This adapted HEdPERF model attempts to isolate realistic HE elements being a multidimensional instrument empirically tested and validated in entirety. The aforementioned instrument was modified (Firdaus, 2006) and adapted to a six factor structure with 72 items, since it was argued that HE has clear and distinct dimensions, namely, academic aspects, reputation, non-academic aspects, access, program issues and understanding.

Although considerable research (Firdaus, 2006; Kimani, 2011; Khodayari \& Khodayari, 2011; Govender \& Ramroop, 2012; Calvo-Porall et al., 2013; Ravichandran, Kumar \& Venkatesan, 2012), has been done using different instruments to measure the impact of SQ on customer satisfaction, virtually few applied HEdPERF dimensions in higher education environments in Kenya. Kimani (2011) who examined perceived service quality among students of universities in Kenya using the correlation approach by studying the six HEdPERF SQ construct measurements established that a 
positive perception of service quality by the students impacts their overall satisfaction. Firdaus $(2005 ; 2006)$ employed factor analysis where dimensions of SQ were identified and relationships between the quality and satisfaction, and among the quality constructs was ascertained. Ravichandran, Kumar and Venkatesan (2012) empirically examined SQ employing HEdPERF among professional engineering institutions in India on 106 respondents using multiple regression established some dominant variables predicting overall SQ. More so more factors (11) loaded that surpassed original HEdPERF scale. By using HEdPERF scale, Kumar and Yang (2014) study found that reputation, access, programme issues and career prospects were determinants of satisfaction among students and that satisfaction exerted positive significant effect on loyalty.

\section{Methodology}

This section briefly explains the research design and methodology which incorporates the research framework, sampling and sample size, survey instrument, and reliability and validity measures of the scales employed.

\subsection{Research Framework and Methodology}

The theoretical framework for this study was developed based on the brief literature reviewed above. The independent variable was service quality while the dependent variable was customer satisfaction, and university service quality was measured on the basis of six dimensions including academic, non-academic, programme, access, reputation and understanding and their effects on customer satisfaction. The conceptual model is illustrated in Figure 1.

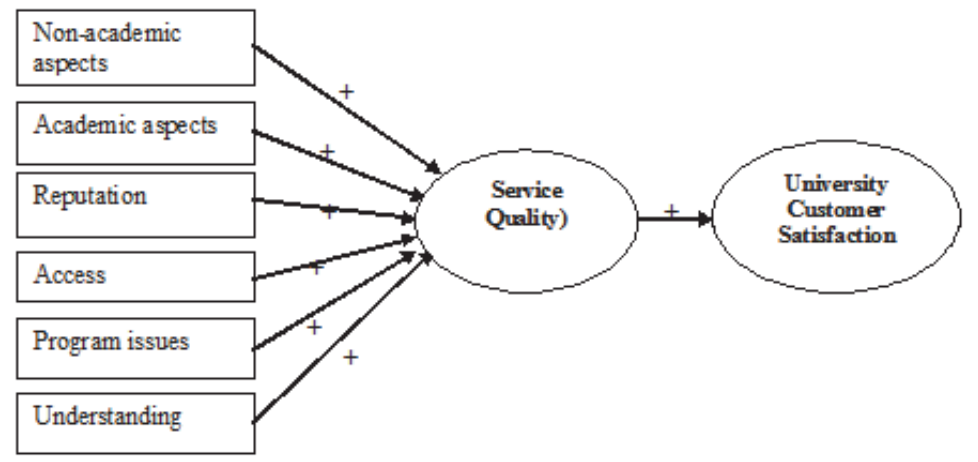

Figure 1: Conceptual Research Framework

\subsection{Hypotheses}

The following hypotheses were postulated to enable exploring associations between private university students' perception of service quality and satisfaction.

H1: The HEdPERF service equality constructs (academic aspects, non-academic aspects, programme aspects, reputation, access and understanding) form the perceived service quality construct and these have a significant positive relationship with overall service quality.

$\mathrm{H} 2$ : There is a positive and significant relationship between students' perceived quality on general service quality.

H3: There is a significant positive association between private university students' perceived service quality and customer satisfaction.

\subsection{Population, Sample Size and Sampling}

The target population for this study was all employees (academic and administrative) and students of select private universities in Kenya. A cross-sectional survey targeted 850 students and employees of which 522 participated in the study (61.4\% response rate) from four universities selected based on geographical location, age, size and ownership in 
the faith-based and "commercial" categories selected using stratified purposeful random sampling technique. The sample size for this study was obtained using the pre-defined sample size calculator proposed by (Krejcie \& Morgan, 1970 in Sekaran, 2006; 293). Thereafter within each stratum, simple random sampling was implemented to select participants in the survey. More specifically, the Catholic University of Eastern Africa (CUEA) and Strathmore University (SU), both are faith-based and located in the city of Nairobi, and the United States International University (USIU) located in city environs, as well as Mt Kenya University (MKU) located in rural area were included in the sample. To participate in the study, the students had to be fully registered in their respective institutions. To ensure full representation by the student body, samples were selected considering the year of study and programme of study, mode of study and both postgraduates and undergraduates were included. The instruments were personally administered to students in their respective universities before beginning of lessons and/or after lessons were complete.

\subsection{Research Instrument}

The questionnaire comprised 7 point scales as Likert scales are generally appropriate measures of attitudes (Cooper and Schindler, 2008). The first part of the questionnaire addressed factors of service quality comprising the following: nonacademic, academic, reputation, access, programme issues and understanding aspects that contributed more to customer satisfaction in private universities. The second part of the questionnaire had statements pertaining to customer satisfaction and overall evaluation of satisfaction

\subsection{Data Analysis}

This study used exploratory factor analysis (EFA) and structural equation models (SEM) to test the hypotheses.SEM is clear and testable, thus competing models can be analyzed, synthesized and understood and, their effect whether direct, indirect or both can be investigated (Schumacker and Lomax, 2004).

\subsection{Scale Reliability and Validity}

The internal consistency of the questionnaire was determined through calculating the Cronbach alpha coefficients using Stepwise Reliability Analysis. Internally inconsistent items were sequentially deleted, therefore maximizing the scales' reliability at 0.70 (Sekaran and Bougie, 2010: 325). Table 1 illustrates that the Cronbach coefficient alphas were acceptable (exceeds 0.7 ); this implying that the measurement instruments were fairly reliable.

Table 1: Instrument Reliability

\begin{tabular}{lcc}
\hline \multirow{2}{*}{ Instrument } & \multicolumn{2}{c}{ STUDENT INSTRUMENT } \\
\cline { 2 - 3 } & Final No. of items & Final Cronbach Alpha coefficients \\
\hline Non-academic Aspects & 23 & 0.941 \\
Academic Aspects & 16 & 0.928 \\
Reputation & 10 & 0.889 \\
Access & 10 & 0.923 \\
Programmes & 3 & 0.854 \\
Understanding & 3 & 0.853 \\
Overall Satisfaction & 7 & 0.933 \\
\hline
\end{tabular}

Construct and discriminant validity were assessed through Exploratory Factor Analysis using Principal Component Analysis with oblique method rotation to summarize the factor loadings under study (Browne, 2001). A factor loading of 0.4 was employed to indicate that the structure was well defined (Hair et al., 2006). Tables 2 show the validity measures for the student instrument.

Following the reliability analysis, some of the constructs had various variables associated with them hence there was a need to reduce redundant variables from these constructs. This was done by performing Spearman's correlation on each construct and highly correlated variables in each construct were grouped together by computing their average. Highly correlated variables carry similar information, hence this was the principle used to reduce the number of variables. The final aggregation of the variables into few but possessing the same information is as illustrated/ included below the structural model (Figure 1). 
Table 2: Rotated Factor Loadings for Student Measurement

\begin{tabular}{ccccc}
\hline Variables & $\begin{array}{c}\text { Non-academic } \\
\text { Quality } \\
\text { FACTOR 1 }\end{array}$ & $\begin{array}{c}\text { Health (Understanding) } \\
\text { Quality } \\
\text { FACTOR 2 }\end{array}$ & $\begin{array}{c}\text { Programme } \\
\text { Quality } \\
\text { FACTOR 3 }\end{array}$ & $\begin{array}{c}\text { Satisfaction } \\
\text { FACTOR 4 }\end{array}$ \\
\hline UND1 & .188 & .738 & .385 & .139 \\
UND2 & .160 & .737 & .310 & .178 \\
UND3 & .237 & $.780^{*}$ & .102 & .127 \\
PROG1 & .225 & .315 & .743 & .113 \\
PROG2 & .302 & .319 & .705 & .126 \\
PROG3 & .252 & .160 & $.785^{*}$ & .192 \\
PROG4 & .080 & .074 & .655 & -.072 \\
NOACD1 & .711 & .039 & .214 & .291 \\
NOACD2 & .722 & .356 & .071 & .197 \\
NOACD3 & $.817^{*}$ & .220 & .102 & .261 \\
ACD1 & .773 & .163 & .208 & .141 \\
ACD2 & .792 & .232 & .093 & .074 \\
REP1 & .482 & .613 & .417 & -.040 \\
REP2 & .610 & .457 & .337 & .113 \\
ACC1 & .576 & .450 & .364 & .104 \\
ACC2 & .574 & .505 & .074 & .176 \\
SAT1 & .077 & .070 & .066 & $.868^{*}$ \\
SAT2 & .182 & .249 & .053 & .751 \\
Overall Service Quality & .272 & .023 & & .579 \\
\hline
\end{tabular}

Note:*Highest factor loadings

Key: UND = understanding, $\mathrm{PROG}=$ programmes, $\mathrm{NONACD}=$ non-academic, $\mathrm{REP}=$ reputation, $\mathrm{ACC}=$ access,

SAT = satisfaction.

It is evident from Table 2 that with respect to the students' perceptions, four factors accounted for the variance among the factors. The extracted factors that loaded in each factor were provided with meaningful names thus; Factor 1 was named non-academic quality, Factor 2 was dubbed health quality (understanding), Factor 3 programme quality and Factor 4 was named satisfaction. However, some dimensions namely; programme quality and understanding quality were found to have no relationship with service quality, their inclusion into the model was making the entire model fit insignificant; hence these were excluded in the final model.

\section{Empirical Findings}

Structural equation modeling (SEM) was performed to explore the relationships among the underlying service quality constructs as indicated by the HEdPERF framework as well as between service quality and customer satisfaction. Tests of the underlying relationships between the six dimensions (academic, non-academic, reputation, access, programme and understanding) and customer satisfaction were also run.

\subsection{Sample Profile}

Table 2 shows that the majority of the students, $66.3 \%$ were aged between 18 and 23 years; $51.6 \%$ were females, with the vast majority $(70.5 \%)$ pursuing first degrees $(70.5 \%)$, and $37.4 \%$ postgraduates. In terms of those pursuing first degrees, $9 \%$ were in their first year's, (37.4\%)and second year (30.1\%), third (20.3\%) and a few (7.1\%) in their fourth year of learning. 
Table 2: Socio-Demographic Characteristics of Student Sample

\begin{tabular}{c|c|c|c}
\hline \multicolumn{1}{c}{ Variable } & Value Label & Number & Valid Percent (\%) \\
\hline \multirow{4}{*}{ Age } & $18-23$ & 346 & 66.3 \\
& $24-29$ & 97 & 18.6 \\
& $30-35$ & 25 & 4.8 \\
& $36-41$ & 17 & 3.3 \\
& $42-47$ & 10 & 1.9 \\
& $48-52$ & 4 & .8 \\
& Above 53 years & 4 & .8 \\
\hline \multirow{2}{*}{ Gender } & Male & 249 & 47.7 \\
& Female & 260 & 49.8 \\
\hline \multirow{2}{*}{ Nature of Study Programme } & Full-time & 411 & 78.7 \\
& Part-time & 99 & 19.0 \\
\hline \multirow{3}{*}{ Programme of Study } & PhD & 7 & 1.3 \\
& Masters & 39 & 7.5 \\
& Bachelors & 368 & 70.5 \\
& Diploma & 36 & 6.9 \\
& Pre-university & 2 & .4 \\
& Professional Course & 22 & 4.2 \\
& No Response & 48 & 9.2 \\
\hline \multirow{3}{*}{ Year of Study } & First & 195 & 37.4 \\
& Second & 157 & 30.1 \\
& Third & 106 & 20.3 \\
& Fourth & 37 & 7.1 \\
\hline
\end{tabular}

\subsection{Structural Equation Model Results}

Table 4 shows the results of the goodness of fit test for the two constructs, namely, university service quality and customer satisfaction and, the resultant structural models from the two data sets. Various indices namely Absolute Fit Measures and Incremental Fit Measures were used to evaluate the model's goodness-of-fit. As a commonly used statistic for model fit indexes, the Chi-square $\left(x^{2}\right)$ was employed in this study to examine the existence of any relationship between the variables in the model (Hair et al., 2006). From the AMOS output reflected in the table 4, it is clear that the model fitted the data well, and therefore proposed model was adequate in explaining the relationship among the variables.

Table 4: Results of the AMOS Analyses of the Resultant Models

\begin{tabular}{|c|c|c|c|c|c|c|c|c|c|c|}
\hline \multirow[b]{2}{*}{ Model } & \multicolumn{10}{|c|}{ Goodness of Fit Measures } \\
\hline & $X^{2}$ & Df & $\mathbf{P}$ & $\begin{array}{c}X^{2} / d f \\
\text { (CMIN/DF) }\end{array}$ & RMSEA & NFI & RFI & IFI & TLI & CFI \\
\hline Student sample & 43.097 & 38 & 0.262 & 1.134 & 0.016 & .989 & .982 & .999 & .998 & .999 \\
\hline Criteria & P>.05 (non-significant) & $\geq 0$ & - & 2 to 3 & $<.04$ & $>.95$ & $>.90$ & $>.90$ & $>.95$ & $>.90$ \\
\hline
\end{tabular}

Note: $X^{2}=$ Chi-square test, $\mathrm{df}=$ Degrees of freedom, RMSEA = Root mean square error of approximation, NFI = Normed Fit Index, RFI = Relative Fit Index, IFI = Incremental Fit Index, TLI = Tucker-Lewis Index, CFI = Comparative Fit Index

Figure1 illustrates the structural equation model outputs for the student data. Drawing results from Table 5 - the parameter estimates for the model and illustration (Figure 1), it is important to point out that in this test the bigger the pvalue the better the fit (contrary to many statistical tests). We found the model to be adequate and this was confirmed by the chi-square value and its corresponding $p$-value. The model had a chi square $\left(x^{2}\right)$ of $=43.097$, Degrees of freedom $=$ 38 and $p$-value $=0.262$. Comparing the $p$-value with level of significance of 0.05 , the $p$-value was greater than 0.05 , $(p>0.05)$ hence the model was declared adequate (Schumacker \& Lomax, 2004; Hair et al, 2006). The fit of the model to the data was checked using absolute measures of model adjustments thus; Comparative Fit Index (CFI), root mean square error of approximation (RMSEA) and the ratio of Chi-square value to degrees of freedom (CMIN/DF). If the CFI value is greater than 0.90 (Hu \& Bentler, 1999), then the model fits the data well. RMSEA values range from 0 to 1 hence, small RMSEA values for example, less than 0.1 means a good fit to the data while values below 0.05 indicate a very 
good fit (Schumacker \& Lomax, 2004). Furthermore, CMIN/DF values less than 3 show better fit. In our analysis CFI = 0.999, CMIN/DF $=1.134$ and RMSEA $=0.016$, as shown in Table 4 above indicating that the model fitted the data well. Similarly, the measures for incremental fit also indicated a proper fit, taking into consideration that Normed Fit Index (NFI), Relative Fit Index (RFI), Incremental Fit Index (IFI) and Tucker-Lewis Index (TLI) had values greater than 0.95. Therefore, the final was considered to be admissible to proceed with structural modeling (Figure 1).

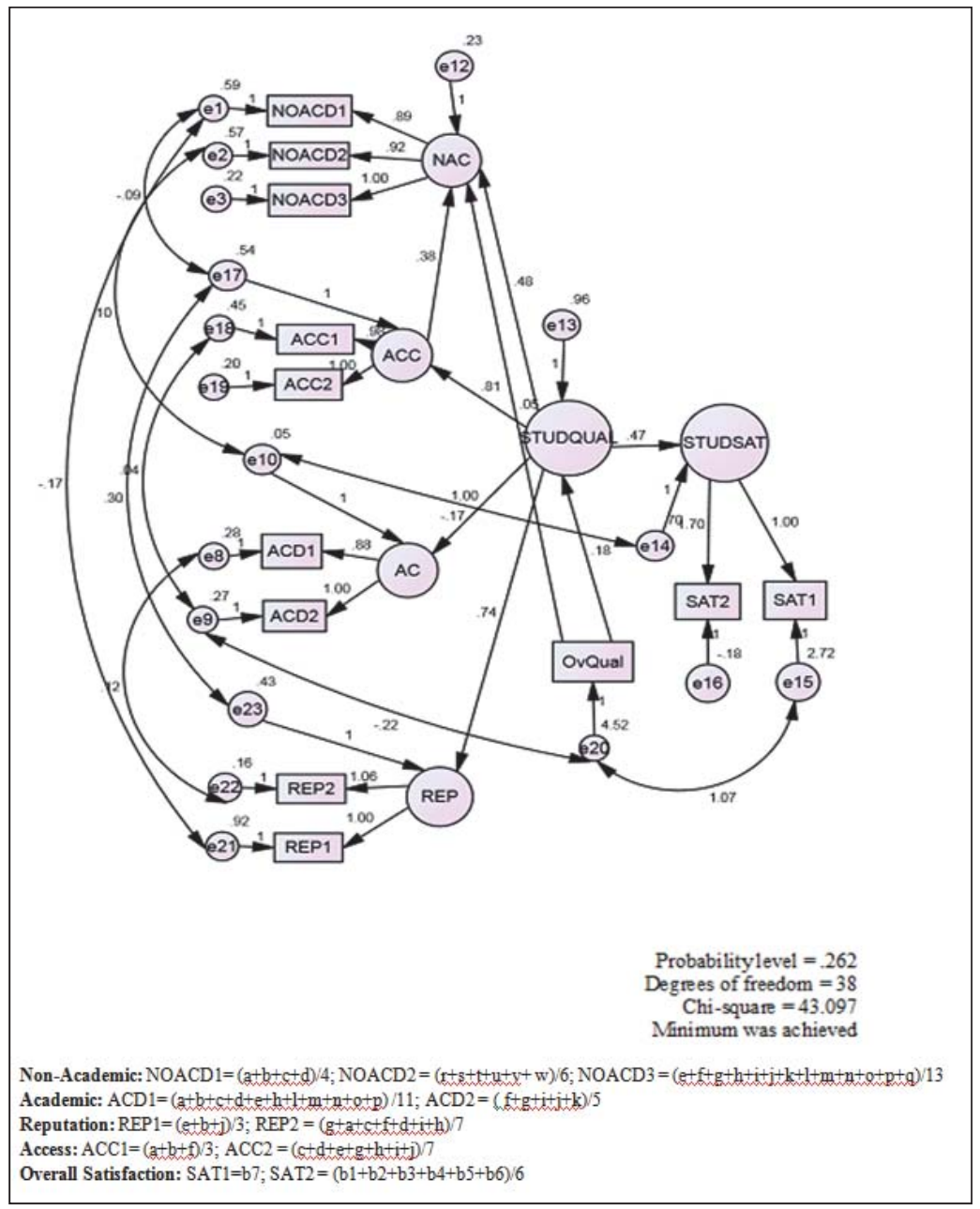

Figure 1: Student Customer - Service Quality Hypothesized Model

\subsection{Hypothesis Testing}

The research hypotheses were tested and the association between the service quality attributes, and between perceived service quality and customer satisfaction was tested using covariance analysis. Table 5 shows that the association among the constructs is significant at $0.05 \%$ level. The results from the student data set showed that in order of strength academic dimension $=1$, access $=0.8130$, reputation $=0.740$ and non-academic $=0.479$ ) were statistically significant $(p<0.0001)$,hence confirming that they are indicators of perceived service quality. The results partly supported hypothesis (H1), and fully supported hypothesis (H2).

From the SEM results, it is evident that service quality has a positive impact on student satisfaction (CR $=4.919$; $p<0.0001)$. The results in Table 5indicate that when quality increases by one unit student satisfaction increases by 0.475 . 
Therefore, we conclude that service quality is positively related with the satisfaction of students. Therefore, research hypothesis ( $\mathrm{H} 3$ ) was supported since there was a statistically significant and positive relationship $(p<0.0001)$. Furthermore, student quality has a positive and significant relationship with overall quality (path coefficient $=0.181 ; t=$ 7.780; $p<0.0001$ ), non-academic was positively related to overall quality with $\beta=0.050, C R=3.064, p=0.002$. As well, Figure 1 shows some correlation structures between error terms for instance, 'e10' is related to 'e14' which are suggested by the 'modification index' output of AMOS after initial model fitting without any correlated error terms. This helps improve the overall model fitting.

Table 5: Model Parameter Estimation and Levels of Statistical Significance - Student Data

\begin{tabular}{lccccccc}
\hline \multicolumn{2}{c}{ Hypothesized Path } & Estimate & Standardised Regression Weights & (S.E.) & C.R. & P-value \\
\hline Student quality & $<--$ & Overall quality & .181 & 0.18 & .023 & 7.780 & $\star \star \star$ \\
Access & $<---$ & Student quality & .813 & 0.81 & .079 & 10.318 & $\star \star *$ \\
Student satisfaction & $<---$ & Student quality & .475 & 0.47 & .097 & 4.919 & $* \star *$ \\
Academic & $<---$ & Student quality & 1.000 & - & Fixed & Fixed \\
Reputation & $<---$ & Student quality & .740 & 0.74 & .077 & 9.576 & $\star \star *$ \\
Non-academic & $<---$ & Student quality & .479 & 0.48 & .111 & 4.309 & $\star * *$ \\
\hline
\end{tabular}

Note: ${ }^{* *}$ means $<0.0001$

\section{Conclusion, Managerial Inferences and Future Research}

This study has shown that service quality constructs have an influence on customer satisfaction. The study revealed a collapse of the original six service quality (academic, non-academic, access, reputation, programmes and understanding) to four, namely, non-academic, academic, access and reputation. An examination of the perceived service quality variables in private universities in Kenya demonstrated had the highest loading on the service quality construct.

The findings revealed that HEdPERF is a valid instrument for measuring quality of services in the higher education sector. By testing the hypotheses postulated, it was revealed that the academic and non-academic aspects were the strongest indicators of service quality, in turn, influencing the satisfaction among students of private universities. The research also established the existence of a positive and significant relationship between the four perceived service quality dimensions and employee and student satisfaction. Moreover, it was found that a positive and significant relationship between students perceived quality on general service quality existed.

An inclusive system for the measurement of SQ in universities and identifying areas where quality suffers will lead to satisfied customers. Service managers and providers will be able to monitor their customers by evaluating their attitudes towards the services they consume, which may assist in the service strategies execution. The findings are significant to policy-makers in the higher education sector in that they may use it to implement sound service policies. The study can be replicated and extended beyond the current scope, to try exploring and understanding the perceptions about SQ from a cross-cultural context, different work practices, methods and environment using the HEdPERF instrument to further validate it as two aspects of SQ i.e. programme and understanding were not confirmed by the study.

\section{References}

Adela, G. (2008). European graduates level of satisfaction with higher education. Higher Education, 57, 1-21.

Alaba, A., R. \& Olanrewaju, A., K. (2012).Service quality dimensions and thesis writing among postgraduate students in southwest Nigeria. Universal Journal of Education and General Studies, 1(7), 188-194.

Bendapudi, N. \& Leone, R. P. (2003). Psychological implications of customer participation in co-production. Journal of Marketing, 67, 1428.

Browne, M.W. (2001). An overview of analytic rotation in exploratory factor analysis. Multivariate Behavioral Research, 36, 111-150.

Calvo-Porall, C., Levy-Mangin, J. P., \& Novo-Corti, I. (2013). Perceived quality in higher education: An empirical study. Marketing Intelligence and Planning, 36(6), 60.

Combrinck, T. (2006). A pilot empirical investigation into student perceptions of service quality at the department of management of the University of the Western Cape. (Master of Commerce dissertation, University of the Western Cape, Cape Town, South Africa).

Cooper, R. D., \& Schindler, S. P. (2008). Business research methods (8th ed.). New Delhi: Tata McGraw-Hill Publishing Company Limited.

DeJager J., \& Gbadamosi, G. (2010). Specific remedy for specific problem: measuring service quality in South African higher education. Higher Education, 60(3), $251-267$.

DeShieldsJr, W. O., Kara, A., \& Kaynak, E. (2005). Determinants of business students satisfaction and retention in higher education: 
Applying Herzberg's two-factor theory. International Journal of Educational Management, 19(2), 128-139.

DeShieldsJr, W. O., Kara, A., \& Kaynak, E. (2005). Determinants of business students satisfaction and retention in higher education: Applying Herzberg's two-factor theory. International Journal of Educational Management, 19(2), 128-139.

Firdaus A. (2005). The development of HEdPERF: A new measuring instrument of service quality for the higher education sector. International Journal of Consumer Studies, 30(6), 569-581.

Firdaus A. (2006). Measuring service quality in higher education: HEdPERF versus SERVPERF. Marketing Intelligence \& Planning, 24(1), 31-47.

Govender, K., K \&Ramroop, S. (2012). Relationship between the postgraduate research students' perception of their role, research climate and service quality. African Journal of Business Management, 6(4), 1642-1651.

Gronroos, C. (2000). Service management and marketing: A customer relationship management approach. (2nd ed.). West Sussex: John Wiley \& Sons, Ltd.

Hair, J. F., Black, W. C., Babin, B. J., Anderson, R. E., \& Tatham, R. L. (2006).Multivariate data analysis (6th ed.). Singapore: PrenticeHall

Ham, L., \& Hayduk, S. (2003). Gaining competitive advantages in higher education: Analyzing the gap between expectations and perceptions of service quality. International Journal of Value-Based Management, 16(3), 223 - 242.

Hasan, H. F. A., \& Ilias, A. (2008). Service quality and student satisfaction: A case study at private higher education institutions. International Business Research, 1(3), 163-175.

Hishamuddin, F. A. H., \& Azleen I. (2008). Service quality and student satisfaction: a case study at private higher education institutions. International Business Research, 1(3), 163-175. Retrieved April 13, 2012, from www.ccsenet.og/jornal.html

Hu, L., \& Bentler, P. M. (1999). Cut-off criteria for fit indexes in covariance structure analysis: conventional criteria versus new alternatives, Structural Equation Modelling: A Multidisciplinary Journal, 6(1), 1-55. DOI: 10.1080/10705519909540118

Kimani, W. S. (2011). Business students' perception of service quality in Kenyan private and public universities. Nairobi, Kenya: CUEA Press.

Khodayari, F., \& Khodayari, B. (2011).Service quality in higher education. Interdisciplinary Journal of Research in Business, $1(9)$, 38 46.

Kumar, J., \& Yang, C. L. (2014). Service quality and loyalty of international students studying in the field of hospitality and tourism. Malaysian Online Journal of Educational Management, 2(3), 97-118.

Marcel, F. \& Harris, C. (2000). If Students are not Customers, What Are They? Academic Medicine. 75(12), 1173-1177.

Materu, N. P. (2007). Higher education quality assurance in Sub-Saharan Africa: Status, challenges, opportunities and promising Practices. World Bank Working Paper No. 124.

Murphys, P. (2009). Higher education access/foundation courses (A research report). Retrieved from National University of Ireland website: http://www.nuigalway.ie/access/documents/access_courses_final_report_3.pdf

Ojo, O. (2010). The relationship between service quality and customer satisfaction in the telecommunication industry: Evidence from Nigeria. Broad Research in Accounting, Negotiation, and Distribution, 1(1), 88-100.

Ong, W. M., \& Nankervis, A. (2012). Service quality in higher education: Students' perceptions in Australia and Malaysia. Review of Integrative and Business Research, 1(1), 277-290.

Ong, W. M., \& Nankervis, A. (2012). Service quality in higher education: Students' perceptions in Australia and Malaysia. Review of Integrative and Business Research, 1(1), 277-290.

Onsongo, J. K. (2011). Promoting gender equity in selected public universities of Kenya. Addis Ababa, Ethiopia: OSSREA Publications.

Quinn, A., Lemay, G., Larsen, P. \& Johnson, D. M. (2009). Service quality in higher education. Total Quality Management, 20(2), 139152.

Ravichandran, K., Kumar, S. A., \& Venkatesan, N. (2012). Students' perceptions on service quality. International Academic Research Journal of Business and Management, 1(1), 23-38.

Sekaran, U. (2006). Research methods for business: A skill building approach (4th ed.). New York: John Wiley \& Sons, Inc.

Sekaran, U., \& Bougie, R. (2010). Research methods for business: A skill building approach (5th ed.). New York: John Wiley \& Sons, Inc.

Trivellas, P., \& Dargenidou, D. (2009b). Organisational culture, job satisfaction and higher education service quality: The case of Technological Educational Institute of Larissa. The TQM Journal, 21(4), 382 - 399.

Wang, I. \& Sheih, C. (2006). The relationship between service quality and customer satisfaction: The example of CJCU library. Journal of Information and Optimization Sciences, 27(1), 193-201.

Yoon, M. H., Seo, J. H. J., \& Yoon, T. S. (2004). Effects of contact employee supports on critical employee responses and customer service evaluation. Journal of Services Marketing,18(5), 395-415.

Yunus, N. K. Y., Ismail, A., Ishak, S., \&Juga, Z., R. (2009). Service quality dimensions, perceive value and customer satisfaction: ABC relationship model testing. IBEJ, 2 (1), 1-18.

Zeithaml V. A., Bitner, M. J., \& Gremler, D. D. (2006). Integrating customer focus across the firm. (4th ed.). New York: McGraw-Hill/Irwin.

Zeithaml, V. A., Bitner M. J., \& Gremler, D. D. (2009). Service marketing: integrating customer focus across the firm. (5th ed.). New Delhi: McGraw-Hill Publishing Company. 